\title{
WHY NONCOMPLIANCE IS SECTOR SPECIFIC
}

Policy matters to noncompliance in the EU. Only five of twenty-three policy sectors account for two-thirds of member state violations of EU law (figure 5.1). The first part of this chapter maps the sector variation in noncompliance in more detail. In the absence of an established theory on sector-specific noncompliance, the second part reviews the field of public policy analysis for arguments that allow us to address sector variation. I link these arguments to the three principal components of the PCP model, showing that different types of policy and their regulatory logic affect compliance costs differently. Unlike distributive and redistributive policy, regulatory policy that seeks to harmonize national regulations at the EU level to correct failures of the Internal Market produces higher costs at the taking stage of the compliance game. While market making is mostly about deregulation, EU harmonization requires the member states to set up new or change existing regulation, to which domestic actors have to adapt their behavior. A statistical analysis in the third part of the chapter evaluates the significance of the different policy factors for noncompliance, controlling for alternative influences. The chapter demonstrates that the EU's noncompliance problems are concentrated in sectors that seek to protect the rights of EU citizens in an increasingly integrated Internal Market. The fourth part of the chapter uses the case of the EU's migration crisis to corroborate the findings of the previous two chapters that politicization renders noncompliance even more likely. The failed attempts to depoliticize the handling of the refugee and migration flows by delegating it to EU institutions also demonstrate the limits of regulatory policy in an increasingly politicized EU. While EU law may have become less costly for 


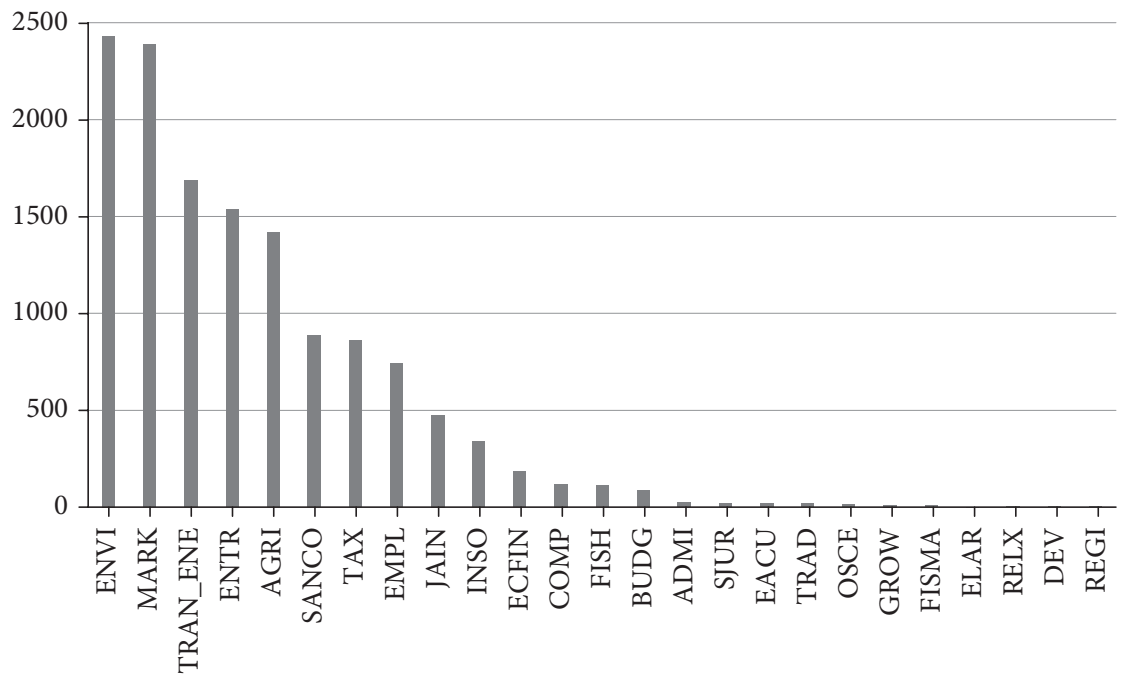

FIGURE 5.1. Total number of reasoned opinions per policy sector, 1978-2017 Source: Own compilation, with data from the Berlin Infringement Database.

Note: $\mathrm{ADMI}=$ Administration; $\mathrm{AGRI}=$ Agriculture; $\mathrm{BUDG}=$ Budget; $\mathrm{COMP}=$ Competition; EMPL = Employment \& Social Affairs; ENTR = Enterprise \& Industry; ENVI = Environment; FISH = Fisheries \& Maritime Affairs; INSO = Information Society \& Media; JAIN = Justice \& Home Affairs; MARK = Internal Market \& Services; OSCE = Organisation of Security and Cooperation in Europe; REGI = Regional Policy; RELX = External Affairs; SANCO = Health \& Consumer Protection; SJUR = Legal Service; TAX = Taxation \& Customs Union; TRAD $=$ Trade; TRAN_ENE $=$ Transport $\&$ Energy.

member states over time, the rise of populism has rendered political conflict surrounding EU regulatory policy more likely. Noncompliance may be declining overall, but market-correcting policy is likely to remain the linchpin of noncompliance in the EU.

\section{Policy Matters!}

Five sectors account for the lion's share of violations against EU law. Two of them, Internal Market and Agriculture, have anchored the European integration project from the beginning. The European Economic Community of 1957 was built around the goals of creating an Internal Market, while providing affordable food for European citizens and a fair standard of living for European farmers through a common agricultural policy (Pinder 1968; Dinan 2004). The other three sectors have been important in flanking the Internal Market. Enterprise \& Industry aims at promoting the competitiveness of European industry mostly by means 
of harmonizing product standards. Closely related to the Internal Market, this sector obtained an independent legal basis in the Maastricht Treaty and became part of the Directorate-General for Internal Market, Industry, Entrepreneurship and SMEs (small and medium-size enterprises) in 2015. The Transport \& Energy sector relates to the regulation of network utilities that are crucial to the Internal Market. The free movement of goods and people depends on transport utilities that can rely on a Europe-wide infrastructure and free access to national transport markets (rail, air, roads). Since services and infrastructure used to be state owned, member states were reluctant to grant the EU any regulatory power. The Maastricht Treaty laid the institutional and budgetary foundations for a common transport policy, breaking up the state monopolies. It also introduced the plan for creating a Europe-wide infrastructure for transport, energy, and telecommunications (Trans-European Networks). Energy became a proper EU competence even later. Before the Lisbon Treaty, the EU had legislated on energy policy. However, it had to draw on its Internal Market and Environment powers to promote the creation of a common energy market, which provides citizens and business with affordable energy and energy services at competitive prices. The Energy Union, officially launched in 2015, is intended to ensure a secure and safe energy supply, reducing the reliance on Russia. Finally, Environment, similar to Enterprise and Transport \& Energy, became a proper competence of the EU rather late, in 1986, with the Single European Act. By that time, however, the EU had already established a comprehensive body of environmental legislation to prevent member states from using national regulations as nontariff barriers in the Internal Market.

The frequent violations of EU law in five core areas of European integration have fueled concerns about a (growing) compliance problem in the EU (see chapter 4). The picture changes, however, when we control for violative opportunities and focus on those eleven sectors that have a substantial number of laws that member states could infringe on. The EU has comprehensively regulated on Environment and Health \& Consumer Protection for more than three decades. Agriculture is among the oldest policy sectors and, naturally, more densely regulated than the younger Environment sector. EU agricultural law is ten times more comprehensive than EU environmental law. JAIN (Justice \& Home Affairs) and Information Society \& Media together total less than one-third of the legislation passed in Environment. Controlling for violative opportunities not only paints a more realistic picture of the leading noncompliance sectors; it helps ensure that noncompliance is driven by sector-specific rather than issue-specific factors (figure 1.5).

The following analysis of sector-specific noncompliance focuses on directives. We lack data on regulations and treaty articles that would allow us to control for 
violative opportunities (see chapter 1). Analyzing directives still yields generalizable results, since the EU's compliance problems are largely confined to directives (see chapter 4).

Once we control for violative opportunities, JAIN and Environment compete for the rank of the no. 1 noncompliant sector (figure 1.5). They are followed at some distance by Information Society \& Media and Health \& Consumer Protection. In the four sectors leading the noncompliance ranking, the vast majority of infringements involve violations of directives. Directives also account for the lion's share of noncompliance in other sectors-with the exceptions of Taxation, Agriculture, and Competition. Legislation in Agriculture is based on regulations to a greater extent than in other sectors (think about the infamous milk quota). In Competition and Taxation, many prescriptions and prohibitions are laid down in treaty articles. Article 102 TFEU, for instance, prohibits monopolies, price discrimination, and exclusive dealing. Likewise, Article 101 bans anticompetitive agreements, including price fixing. According to Article 107, states must not aid or subsidize private parties in distortion of free competition. Because of the EU's limited competencies on taxation, tax-related EU law is heavily based on the free movement of capital (payments), people (workers), services (right of establishment), and goods (customs union). The four freedoms build the core of the Internal Market and therefore are directly protected by treaty articles.

Directives account for at least two-thirds of official infringements in the leading noncompliance sectors. Between 1978 and 2012, EU member states violated on average more than 80 percent of the directives adopted in each of these sectors. In the case of JAIN, every directive has been violated at least once (figure 5.2). The following section briefly outlines the five top noncompliance sectors.

The objective of JAIN is to establish an "area of freedom, security and justice." Its core is the border-free Schengen area. The abolishment of mutual border controls among the twenty-six participating countries, four of which (Iceland, Liechtenstein, Norway, and Switzerland) are not members of the EU, has created the necessity for a common policy on asylum, immigration, and external border control. Within the EU, the freedom of movement has led the member states to coordinate their fight against terrorism, human trafficking, sexual exploitation, illicit drug trafficking, money laundering, corruption, counterfeiting, and computer crime. Finally, JAIN legislation is intended to ensure EU citizens' fundamental rights, including access to the local justice system, and protect them against discrimination on the grounds of sex, racial or ethnic origin, religion or belief, disability, age, or sexual orientation. The most frequently violated directive is the citizens' right directive to guarantee free movement and residence of EU citizens throughout the EU. ${ }^{1}$ The majority of the other front-runners for violation involve the rights of immigrants and the treatment of asylum seekers, 


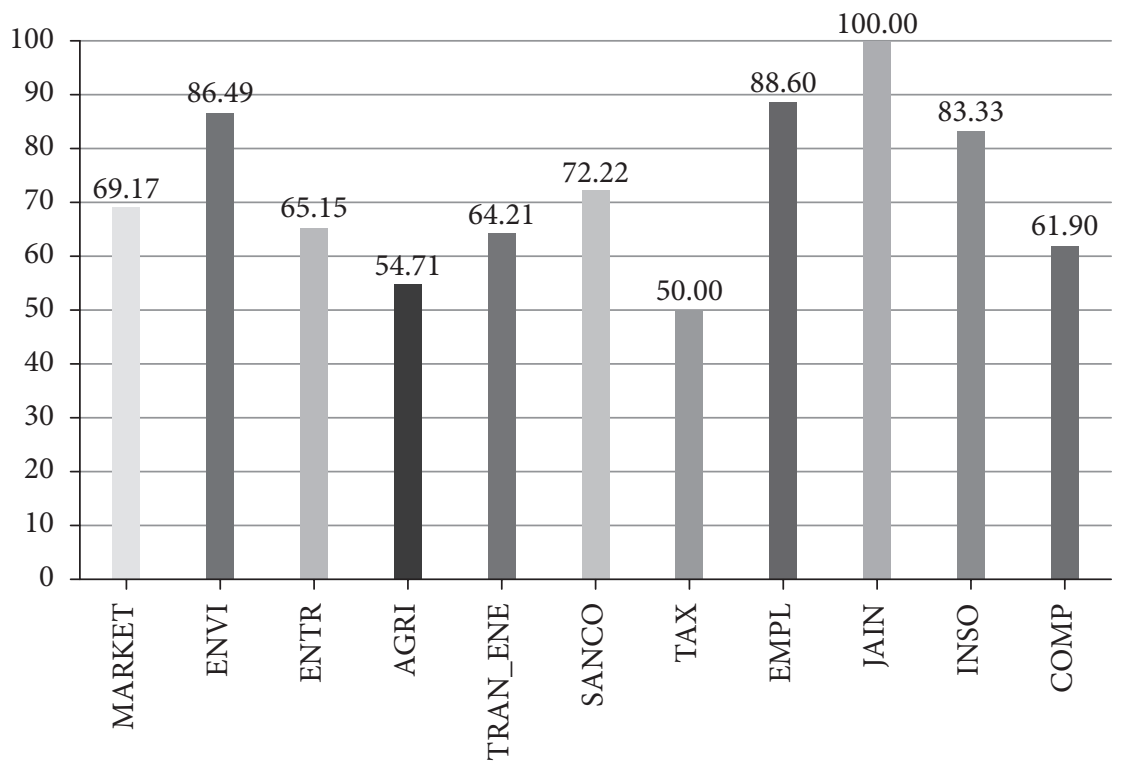

FIGURE 5.2. Percentage share of officially infringed directives in relation to all directives adopted by policy sector, 1978-2012

Source: Own compilation, with data from the Berlin Infringement Database.

for instance in regard to the status of third-country nationals and minimum standards for legal recognition. ${ }^{2}$ With the migration crisis, noncompliance has intensified in this area. In 2015, the Commission took legal action against virtually all member states for not applying the five directives the EU had adopted between 2001 and 2011 (European Commission 2016, 19-20). Individual rights of nondiscrimination in employment and occupation and the protection of personal data also figure prominently. This includes the retention-of-data directive of 2006, which required member states to store citizens' telecommunications data for a minimum of six months and at most twenty-four months. ${ }^{3}$ In 2014, the ECJ annulled the directive, since it considered the general and blanket retention of data a violation of fundamental rights. Finally, the harmonization of criminal law with regard to environmental pollution has gained prominence. ${ }^{4}$ Given its younger age and lower regulatory density, JAIN is likely to remain the least-complied-with policy sector in the EU.

Environment (ENVI) started as trade policy, since the Treaty of Rome did not foresee any competence for the $\mathrm{EU}$ in this sector. Yet, from the very beginning, the European Commission pushed policies that went beyond harmonizing national regulations to prevent their use as nontariff barriers. The wild birds directive was 
adopted as early as 1979-before the Single European Act conferred on the EU the power to legislate on the environment. ${ }^{5}$ It was the first piece of EU legislation on nature conservation and got a complete overhaul thirty years later. ${ }^{6}$ Together with the much younger fauna, flora, habitat directive passed in 1992, it accounts for almost a fifth of all infringements in Environment; nature conservation is the least-complied-with area of EU law in the history of the EU. ${ }^{7}$ Environmental impact assessment (EIA) and urban waste water treatment (UWWT) are two other front-runners, not only in Environment but in the EU as a whole (see chapter 4). EIA, which came into force in 1985, prescribes procedures for the licensing of public and private projects with significant effects on the environment. ${ }^{8}$ UWWT was adopted in 1991 under Article 130(s) of the Single European Act, which granted the EU the power to enact proper environmental legislation. It sets standards for the treatment and discharge of waste water from cities and certain industrial sectors. ${ }^{9}$ Some of the other least-complied-with directives conform more to the original idea of EU environmental policy as promoting free trade, for instance by setting common limit values for air and water pollutants, such as sulfur oxide or nitrate.

Information Society \& Media (INSO) ${ }^{10}$ aims at creating the Digital Single Market by 2018. It is an advancement of the Internal Market, which was officially completed in 1992. The free movement of data entails free and fair access to electronic communications services and electronic communications networks, for both providers and consumers. Accordingly, EU legislation seeks to harmonize user rights, the processing of personal data, and the protection of privacy. The most infringed directives, which account for more than 80 percent of all infringements in this sector, concern the EU's attempt to set up a common regulatory framework on electronic communications networks and services (Nijenhuis 2013). By far the least-complied-with directive is the universal service directive adopted in $2002^{11}$ and amended in $2009 .{ }^{12}$ It seeks to ensure the availability of a minimum set of good-quality electronic communications services accessible to all users at an affordable price, which member states have to ensure, including to those users who do not yet have a connection to public communications networks (telephone, internet) because they live in a remote area. Low-income users are entitled to special tariffs. Consumers also receive the right to change their phone company while keeping their old number and to be informed of changes in prices and tariffs.

Health \& Food Safety (SANCO) is the core area of consumer protection. It entails a series of laws on food and product safety, consumer rights, and public health. The most infringed directives seek to protect consumers against unfair terms in consumer contracts, ${ }^{13}$ unfair business-to-consumer commercial 
practices,$^{14}$ or against health risks emanating from foodstuffs, particularly those entering from third countries that are not members of the EU. Some directives are about animal protection, for example the laying-hens directive, which sets minimum standards for the welfare of laying hens. ${ }^{15}$ Such regulations are also to prevent distortions of competition between producers in different member states.

The literature has not paid much attention to variation in noncompliance between policy sectors, even though research shows that variation is not random and may be even larger than between member states (Steunenberg 2007; Börzel et al. 2007; Börzel, Hofmann, and Panke 2011; Zhelyazkova, Kaya, and Schrama 2016). The neglect of the policy dimension in compliance research may be related to the lack of clear or intuitive patterns, as we find with regard to time (decline since the 1990s) and member states (North v. South; West v. East). The majority of the eleven most infringed sectors follow the secular trend of declining noncompliance analyzed in chapter 4. Only in JAIN and Transport \& Energy have infringements increased.

The increase in JAIN and Transport \& Energy seems to be at least partly driven by the new member states that joined in 2004 and 2007. Overall, eastern enlargement has mitigated rather than exacerbated the EU's compliance problems (see chapters 3 and 4). In most sectors, the new member states range among the top compliers. In JAIN, however, nine of the twelve newcomers are leading the noncompliance ranking. In Transport \& Energy, the CEE countries still diverge from their exemplary compliance behavior, mingling with the old member states.

What do JAIN, Information Society \& Media, Environment, and SANCO have in common? What renders these four most noncompliant sectors different from the other sectors that do comparatively better and conform to the general patterns of cross-time and cross-country variation?

Unlike compliance research in IR, implementation studies on EU policy making have paid more attention to variation in violations of EU law across sectors than across member states (Treib 2008; Knill 2015). These studies tend to be variable driven, though. There are no theories (yet) to account for policy-related variation in noncompliance behavior. Similar to implementation research in the field of public policy analysis, various case studies have identified a multitude of factors that may cause problems of noncompliance at the sector level. These studies provide important insights into the causes of policy noncompliance. However, they tend to compare (if at all) only two or three policy sectors, usually concentrating on social and environmental policy, while other sectors have remained largely unexplored (Luetgert and Dannwolf 2009; Toshkov et al. 2010; Zhelyazkova, Kaya, and Schrama 2016, 2017). Thus, the external validity of qualitative research tends to be limited (Haverland, Steunenberg, and van Waarden 2011). This has started to change with the quantitative turn in EU research. 
A growing number of studies have been using statistical methods to test explanations similar to those of case studies across a larger $\mathrm{N}$. The majority of them still focus on the transposition of a limited number of directives in a limited number of sectors by a limited number of member states (Borghetto, Franchino, and Giannetti 2006; Berglund, Grange, and van Waarden 2006; Toshkov 2007b, 2008; Haverland and Romeijn 2007; Thomson 2007; König and Luetgert 2009; Luetgert and Dannwolf 2009). These studies narrow the dependent variable to timely transposition by a subset of member states in selected sectors. They usually do not develop genuine policy explanations either. Rather, the literature uses dummy variables and relies otherwise on factors that are derivative of issuespecific or country-specific variables discussed in chapter 3 and 4, respectively.

In short, there is solid empirical evidence that policy matters, but we do not know exactly why and how. Rather than drawing on explanations that focus on issue-specific and country-specific factors (dis)aggregated at the sector level, this chapter uses the PCP model to develop a genuinely sector-specific explanation to solve the puzzle of why noncompliance is concentrated in a handful of sectors.

\section{Policy Matters-but Why?}

While often criticized for its complex models, public policy research offers theoretical arguments for why noncompliance varies across policy sectors. These arguments focus on the costs of compliance at the shaping stage.

\section{Sector-Specific Explanations}

\section{REGULATORY VERSUS NONREGULATORY POLICY}

"Policy determines politics," said Theodore Lowi $(1972,299)$. To state his argument, he distinguished four different types of policy in terms of the likelihood and applicability of coercion. With regard to the PCP model, policy types vary in the extent to which they produce compliance costs for the member states (König and Luetgert 2009). Constituent policy refers to the structures of government and administration. In the case of the EU, this would mostly include treaty reforms rather than directives and regulations. Affecting primary rather than secondary EU law, constituent policy is not so relevant for explaining sector variation in noncompliance. The remaining three policy types, in contrast, carry different implications for compliance costs. Distributive policy allocates public resources among alternative users (Majone 1996, 63). Examples include public security, education, and infrastructure. Their costs are borne by the collectivity of taxpayers rather than by a specific group (Schumann 1991). Distributive policy is also 
less costly in its enforcement, since actors do not have to change their behavior to ensure compliance. Their implementation is mostly a question of capacity. This is also true for redistributive policy, such as Agriculture and Regional Policy. Yet, unlike Research or Education, redistributive policy transfers resources from specific social groups, member states, or regions to others. It creates clear winners and losers, which renders agreement at the shaping stage difficult. Once the policy is adopted, however, its taking should not be much of an issue. Regulatory policy, finally, prohibits or prescribes certain behavior. Unlike distributive and redistributive policy, regulatory policy does not involve direct public expenditure costs. However, prohibiting mergers, price collusions, state subsidies, unfair terms in consumer contracts, or discrimination on grounds of sex, racial or ethnic origin, religion or belief, disability, age, or sexual orientation entails benefits for the broader society but incurs significant costs for some parts of it (Wilson 1980). So do mandating the reduction of environmental pollution, the application of certain licensing procedures, the access to public communication networks, or the protection of personal data. Air pollution control regulations, for instance, reduce public health risks but require industry to introduce new abatement technologies. Since actors are likely to resist such costs, regulatory policy requires enforcement, which is not only a matter of capacity but also politicization when actors mobilize against the costs they have to bear.

A few scholars have worked with Lowi's typology to address issues of implementation and compliance. Most prominently, Majone argued that the costs of policy formulation and decision making for regulatory policy are relatively low at the shaping stage but often significant-in material and political terms-at the taking stage. (Re)distributive policy (Agriculture, Regional Policy) require direct public expenditures; these costs need to be dealt with at the stage of decision making. Regulatory policy (Internal Market, Competition, Environment, SANCO), in contrast, shift the costs to implementation at the domestic level, where implementing authorities and societal actors might be neither willing nor able to bear them (Majone 1993, 1996). Accordingly, noncompliance with EU law should be higher in regulatory as compared to nonregulatory policy sectors.

The difference between (re)distributive policy and regulatory policy with regard to the costs arising at the shaping versus the taking stage explains why the EU has developed into a "regulatory state," one that lacks the power to make truly (re)distributive policy (W. Wallace 1983; Majone 1993, 1994). The EU's tax and spending capacity is limited. The one exception is Agriculture, which has always accounted for a significant share of the EU budget (more than two-thirds until the 1990s), benefiting less than 5 percent of the EU population. Still, the EU's (re)distributive capacity is less than 5 percent of what its member states do. The vast majority of EU law is regulatory in nature. This may explain why more than 
90 percent of official infringements refer to violations of regulatory policy, and the most noncompliant sectors are predominantly regulatory.

With the establishment of the political union in the Maastricht Treaty, the EU began to go beyond classical regulation, moving into the area of internal security and the individual rights of its citizens. Its competencies for (re)distribution have remained limited (Scharpf 2003). At the same time, EU law has increasingly interfered with national sovereignty on (re)distribution. The convergence criteria of the Maastricht Treaty, the Stability and Growth Pact, the Fiscal Compact, and the European Semester circumscribe the fiscal powers of the member states (Scharpf 2015; Streeck and Elsässer 2016). The EU's attempt to manage the sovereign debt crisis has significantly constrained domestic economic and social policy, producing or at least exacerbating redistributive effects that are increasingly attributed to the EU (Hix 2015; Scharpf 2015; Polyakova and Fligstein 2016). Moreover, the financial guarantees, assistance, and interventions of the European Stability Mechanism and the ECB have directly or indirectly caused massive redistribution among and within the member states. The euro crisis has definitely turned the EMU into a redistributive issue by increasing the financial scale and the public visibility of redistribution.

Despite the redistributive consequences of the common currency, the member states have remained unwilling to change the treaties to give the EU substantial redistributive authority. They continue to have difficulty in finding the necessary consensus on the structures and goals of the EU as a polity-for example, with regard to the degree of state intervention into markets (W. Wallace 1983; Majone 1994). Agreement on regulatory policy, in contrast, is easier, since costs only become salient in the implementation. Genschel and Jachtenfuchs (2016) contend that EU regulatory policy is still less prone to noncompliance because it is less likely to be politicized. While EU regulatory standards may incur costs at the domestic level, their redistributive implications are concealed since they impose uniform legal obligations on all member states—everybody should have to bear the same costs. Moreover, regulatory policy does not directly interfere with core state powers required for distributive and redistributive policy, such as public security, taxation, or welfare; the latter policies lie at the heart of state sovereignty, where EU law is more likely to meet domestic opposition (Genschel and Jachtenfuchs 2016).

In sum, regulatory policy is likely to entail higher compliance costs than distributive and redistributive policy. This facilitates policy adoption at the shaping stage but creates problems at the taking stage, making noncompliance more likely. Philipp Genschel and Markus Jachtenfuchs (2016) argue the opposite-noncompliance with regulatory policy should be lower because compliance costs are less likely to become politicized at the taking stage. Regulatory policy is less publicly 
visible and does not concern politically sensitive issues. Public visibility and political sensitivity are central to the PCP model. Regulatory policy may or may not interfere with core state powers. The fauna, flora, habitat directive or the services in the Internal Market directive do not, but they still became politicized in virtually all member states (chapter 4). The redistributive consequences of regulatory policy make politicization more likely. As a result, the PCP model expects noncompliance with regulatory policy to be higher than with nonregulatory policy.

\section{MARKET-CORRECTING VERSUS MARKET-MAKING REGULATORY POLICY}

Given the predominance of regulatory policy in the EU, Zürn (1997) refined Majone's argument on compliance costs. His starting point was the distinction within regulatory policy between regulations aimed at market making (negative integration) versus market correcting (positive integration). The distinction was originally introduced by Pinder (1968) in his analysis of the European Economic Community. Negative integration refers to the opening of existing markets to foreign competition by eliminating tariffs, taxes, quotas, and other protectionist policies, such as state subsidies. Negative integration also entails the creation of new markets by breaking up state monopolies as they traditionally existed for utilities, such as telecommunications or energy (Pinder 1968). While negative integration is about deregulation and privatization at the national level, positive integration aims at reregulation at the EU level, removing nontariff barriers. To create and maintain a level playing field for suppliers and consumers, member states agree on common European standards on the quality, safety, and labeling of products and production processes (e.g., regulations on food standards, packaging, the use of chemicals, working hours).

Nine years after its ratification, the Treaty of Rome, Pinder concluded, was "strongly biased in the direction of negative integration and away from positive integration" (Pinder 1968, 99). About thirty years later, Scharpf confirmed the structural asymmetry between negative and positive integration and related it to different dynamics in EU decision making and the market-friendly jurisdiction of the ECJ (Scharpf 1996, 1997b, 2001a). The member states agreed to create an Internal Market in 1957. They have shared an interest in harmonizing national regulations at the EU level to prevent them from being used as nontariff barriers to protect certain sectors of the national economy against foreign competition. At the same time, member states have found it difficult to agree on the extent to which the Internal Market should be reregulated concerning the internal economic competition unleashed by EU-induced deregulation at the domestic level. The ECJ interpreted the treaties in a way that elevated the four market freedoms to the status of economic liberties to be protected not only against protectionist 
discrimination but also nondiscriminatory constraints, for instance in the form of collective labor rights (Scharpf 2016b). "Integration through law" (Cappelletti, Seccombe, and Weiler 1986) reinforced the asymmetry of market making over market correcting. Majone saw the main difference between regulatory and nonregulatory policy in the costs the former incurs at the taking stage and the latter at the shaping stage. Scharpf contended that market-correcting policy has redistributive consequences that already materialize at the shaping stage of the compliance game, making its adoption as difficult as in the case of (re)distributive policy.

Zürn systematically extended the distinction between positive and negative integration to the taking stage. He hypothesized that member states are more likely to infringe on positive or market-correcting policy (Zürn 1997; cf. Börzel, Hofmann, and Sprungk 2003; Toshkov 2008). The taking of EU policy designed to facilitate negative integration may incur costs for some domestic actors, such as companies that are not internationally competitive. However, market-making policy does not require member states to take action or develop and police the application of new legislation. In order to remove obstacles to market integration, member states mostly have to abstain from interfering with the free flow of market forces by not levying import tariffs and export fees and not controlling borders. Compliance is less a matter of capacity. Market-correcting policy, in contrast, explicitly requires states to actively interfere in market and society (Scharpf 1999; H. Wallace 2005). The implementation of common environmental, health, or labor standards demands more capacity and is more prone to politicization than the control of mergers, price collusions, or state subsidies. Member states have to enact new legislation, invest additional administrative resources, and strengthen administrative coordination to enforce it. At the same time, the "regulatory competition" (Héritier 1996) among the member states makes any compromise at the EU level likely to become subject to domestic opposition, for instance by business sectors that face higher production costs because they have to invest in new abatement technology or pay higher wages. Taking marketcorrecting policy requires more capacity to cope with the costs and is more likely to become politicized.

In sum, the PCP model proposes that regulatory policy carries a greater risk of noncompliance than other policy types, particularly if its regulatory logic is market correcting rather than market making. There are a few other factors identified in the literature that provide sector-specific explanations for noncompliance with EU law. They have not always been linked back to some theoretical framework. Nor are they inherent to specific policy types. However, the number of years the EU has had the competence to legislate on a sector, the level and scope of its competencies and their public (nonacceptance), and the 
regulatory density of EU legislative action vary across sectors, affecting compliance costs. They therefore serve as control variables.

\section{AGE}

The "EU age" of a sector-that is, the length of time the EU has had the competence to adopt laws - may matter for the capacity of member states to cope with compliance costs (Börzel, Hofmann, and Panke 2011). Agriculture, Internal Market, or Competition have been subject to EU policy making since the early days of European integration. The member states have had sixty years to build up the capacity to implement EU legal acts (Berglund, Grange, and van Waarden 2006; Haverland, Steunenberg, and van Waarden 2011). They also have gained more administrative experience with the implementation of EU law (Steunenberg and Rhinard 2010). JAIN, in contrast, is one of the youngest sectors. It was introduced with the Maastricht Treaty in 1992 and only became fully supranationalized with the Lisbon Treaty of 2010. As older sectors, Agriculture, Internal Market, or Competition should see more noncompliance than younger sectors, such as JAIN and Employment \& Social Affairs.

\section{EU COMPETENCIES}

The more competencies the EU has to legislate in certain policy sectors, the more likely member states are to face EU laws that do not reflect their preferred outcome, imposing compliance costs. To measure the range of the EU competencies, Lindberg and Scheingold distinguished between scope and locus (level) of decision making (Lindberg and Scheingold 1970, 67-71). While scope relates to the initial expansion of EU authority to new policy areas, locus or level stresses "the relative importance of Community decision-making processes as compared with national processes" (1970, 68; cf. Börzel 2005). Policy sectors such as Internal Market, Competition, or Environment, in which the EU has comprehensive legislative competencies (broad level and wide scope), are expected to come with higher costs than policy sectors such as Taxation, in which the EU can legislate only on selective or minor issues. The broader the level and the wider the scope of EU competencies, the more member states might be unwilling or unable to bear the costs that come with the implementation and enforcement of comprehensive and far-reaching EU policies. ${ }^{16}$ Given the EU's comprehensive competencies in Internal Market, Competition, or Environment, we should expect more noncompliance in these sectors than in Taxation or Employment \& Social Affairs.

\section{OPPOSITION TO EU COMPETENCIES}

Public attitudes toward the EU vary not only across member states (chapter 3). EU citizens also differ in the extent to which they support or oppose EU competencies 
over policy sectors (Zhelyazkova, Kaya, and Schrama 2016). Public opinion data shows that citizens are supportive of the EU legislating on Environment but prefer their member states to remain in charge of Employment \& Social Affairs. We should expect more noncompliance in the latter sectors owing to the greater opposition against the $\mathrm{EU}$ as the rule-making institution, rendering politicization more likely. I already found that higher EU opposition leads to less rather than more noncompliance (see chapters 3 and 4). We shall see whether this counterintuitive finding also holds when sector-specific factors are included in the analysis.

\section{REGULATORY DENSITY}

Another factor that shapes the costs of compliance across different sectors is regulatory density. The more European laws that exist in a policy sector, the lower the need in the member states to adapt already harmonized (or Europeanized) domestic laws to newly passed directives (Mastenbroek 2003; Kaeding 2006; Haverland and Romeijn 2007). Taking EU policies in sectors with high regulatory density, like Agriculture and Enterprise \& Industry, should be less costly and require less capacity and domestic power as compared to JAIN, Information Society \& Media, and Taxation.

\section{Issue-Specific Explanations}

Some studies aggregate issue-specific explanations of noncompliance at the sector level. Rather than including the entire list of issue-specific factors, I will limit myself to the factors that chapter 4 found to be significant in explaining temporal variation in noncompliance and that are unequally distributed across sectors (cf. Haverland, Steunenberg, and van Waarden 2011; Steunenberg and Rhinard 2010; Berglund, Grange, and van Waarden 2006; Toshkov 2008; Luetgert and Dannwolf 2009).

\section{NOVELTY}

New legislation is more demanding than amending legislation. The former creates a greater misfit with existing domestic legislation, which needs to be adapted, imposing higher compliance costs that member states may not be willing or able to bear. Environment and Employment \& Social Affairs, which have a higher share of new legislation, should be more prone to noncompliance than Agriculture and Competition.

\section{COMPLEXITY}

Complex legislation is more demanding on the capacities of the member states. Highly complex sectors, such as Information Society \& Media and JAIN, should show more noncompliance than Agriculture and Enterprise. 


\section{DELEGATION}

Delegation reduces the risk of politicized implementation, requiring less domestic power for enforcement. Agriculture, Enterprise, and Competition, with their higher share of delegated legislation, should feature less noncompliance than Environment, Employment \& Social Affairs, or JAIN.

\section{EU-LEVEL CONFLICT}

The amendments the European Parliament introduces during the adoption of directives increases the risk of those directives being politicized in their implementation. Environment and Health \& Consumer Protection, where parliamentary interference is higher, are more likely than Competition and Agriculture to face domestic opposition to compliance.

While controlling for issue-specific factors, I do not include country-based explanations in the sector models. Partisan preferences (König and Luetgert 2009), bureaucratic quality (Steunenberg and Rhinard 2010), or organized interests (Steunenberg and Rhinard 2010; Luetgert and Dannwolf 2009; König and Luetgert 2009) and subnational authorities (Borghetto and Franchino 2010; Steunenberg and Rhinard 2010) may vary significantly within member states, producing legislative and bureaucratic drift "within sector-specific boundaries" (Steunenberg and Rhinard 2010, 497). This is not the same, however, as to argue that all member states are similar with regard to these sector-specific differences, resulting in similar noncompliance patterns. There are neither theoretical reasons nor empirical evidence suggesting that the capacity or the power of member states is higher in particular sectors than in others. Party preferences do not converge along sectors either. Parties belonging to the same side of the political spectrum seldom share the same preference for how to deal with an entire policy sector. The German Christian Democrats and the Hungarian Fidesz are members of the European Peoples Party, the conservative group in the European Parliament. Yet their preferences on individual rights, rule of law, asylum and migration, or environmental and social standards greatly diverge (Scully, Hix, and Farrell 2012). The same is true for the social democratic parties in France, Spain, Germany, Sweden, and Eastern Europe that are members of the Party of European Socialists.

Finally, member states also vary with regard to their ability to shape policy outcomes as to reduce compliance costs, as well as in the power to resist them. Yet no single member state is in the position to dominate at the shaping stage of the compliance game (Héritier, Knill, and Mingers 1996; Börzel 2002a). It makes little sense, therefore, to disaggregate country-specific power and capacity at the sector level.

The control variables can be grouped into factors that affect the compliance costs of a sector and factors that render politicization more likely. With regard 
to the former, noncompliance becomes more likely owing to higher compliance costs the broader and deeper a sector is integrated (EU competencies); the more directives the EU adopts, which set new rather than amend existing legislation (novelty); and the more issues these directives regulate (complexity). The number of years the EU has been active in a sector mitigates the expected positive effect of costs on noncompliance (age). So does the number of already existing laws member states have to comply with (regulatory density). The adoption of a directive by Council and EP (non-delegation), the interference of the EP in the adoption of a directive (EU conflict), and low domestic support for the EU legislating on a sector (EU opposition) increase the likelihood of politicization.

\section{Evaluating Factors Influencing Policy Variation}

Since I am interested in policy explanations, I focus the statistical analysis on policy type and regulatory logic as genuine sector characteristics. The more indirect sector variables and issue-specific factors that are assumed or empirically observed by the literature will be included in the analysis as control variables.

\section{Data and Methods}

The regression models in chapters 3 and 4 took member states ${ }^{17}$ and individual directives ${ }^{18}$ as their unit of analysis, respectively. The ensuing analysis includes annual observations per policy sector and employs the number of infringements per policy sector per year as its dependent variable. More specifically, the dependent variable is based on 10,135 observations concerning infringements against directives between 1978 and 2012, as allocated to eleven policy sectors in the Commission sources.

The EU publishes data on its legislation on EUR-Lex, including information and search options on the type of legal act, period of validity, and other characteristics. However, it does not provide for a clear categorization of policy sectors. The multilingual thesaurus EuroVoc, maintained by the Publications Office of the European Union, ${ }^{19}$ links numerous topics, subject matters, and directory codes to a legal act. I therefore apply the categorization of infringement proceedings, which the European Commission uses in its Annual Reports on Monitoring the Application of EU Law. It clearly indicates the (main) policy sector concerned by listing infringements according to the Directorate-General responsible for handling the proceeding. The categorization of sectors by the DG in charge of the infringement comes closest to the categories used for coding the 
infringements by sectors. It also has an advantage over the treaty base in general. Enabling treaty articles, such as Article 100 EC Treaty, served as the legal basis for many enterprise and environment directives, before a proper primary legal base was established by treaty reforms. The structure of most policy sectors has changed over time. The eleven sectors under investigation have remained rather constant, though. The DGs for Health \& Consumer Protection and Transport \& Energy were separated in 2004 and 2010, respectively, because of the growing number of member states. I continue to aggregate them.

Using the directory codes allows me to draw on the data set Legislative Production in the EU, 1967-2009 compiled by Dimiter Toshkov to compute the number of adopted directives per sector and year as a proxy for the legislation in force. A lag of three years matches adoption and official infringement of a directive controlling for the six to twelve months it takes for a directive to enter into force, and the twenty-four to thirty-six months that elapse between the Commission registering a possible infringement and sending out a reasoned opinion.

\section{POLICY TYPE}

The coding of policy sectors as regulatory vs. nonregulatory is a challenge. EU law is predominantly regulatory owing to the limited competencies the EU has for redistribution (Börzel 2005; Genschel and Jachtenfuchs 2016). Fishery is clearly redistributive, as it sets limits to what member states are allowed to fish. So is Regional Policy with regard to the fiscal transfers member states receive. Both sectors, however, are not included in the sample because of the low number of adopted directives (less than one directive in two years). For the same reason, I dropped Research and Education, which are redistributive policies. Agriculture is the one policy sector in the sample that contains a substantial redistributive dimension, in the form of farm subsidies, which still account for a third of the EU budget. EU price and market support has been politically justified by considerations of food security, declining living standards of farmers, and structural and natural disparities between the various agricultural regions in the EU (Knudsen 2009). While some member states benefit more than others, redistribution is more indirect and, as expected by Majone, becomes an issue of contention every seven years when the EU's budget is negotiated at the EU level rather than in everyday implementation (De la Fuente and Doménech 2000; Aksoy 2010).

\section{REGULATORY LOGIC}

Internal Market, Competition, and Taxation \& Customs Union are the three sectors that are predominantly market making. Internal Market aims at removing obstacles to trade in goods and services, such as tariffs, taxes, quantitative restrictions on imports (e.g., quotas) and measures having equivalent effect. EU 
competition law (Articles 101-109 TFEU) seeks to prevent behavior of states and companies that harms competition in the Internal Market. This entails the control of state aid, mergers and acquisitions, and the formation of cartels, collusion, and other forms of anticompetitive practices. The customs union protects the external borders of the Internal Market by setting common external tariffs. The coordination of taxation policy across the $\mathrm{EU}$ is intended to prevent indirect state aid, such as offering tax credits to (foreign) businesses. A prominent example is the European Commission ordering the Irish government to collect more than $€ 14$ billion in taxes, including interest, from Apple in 2018.

Employment \& Social Affairs has clearly market-correcting goals (Article 151 TFEU) since it aims at improving living and working conditions to protect workers' health and safety. In a similar vein, Environmental and Health \& Consumer Protection are designed to correct market failures by setting production and product standards to fight environmental pollution (Article 191 TFEU) and protect the health in general (Article 168 TFEU), for workers (Article 153 TFEU) and consumers (Article 169 TFEU).

The other sectors are more difficult to classify and entail some broad generalization. Every policy sector or, in fact, every EU legal act may entail regulatory elements or some elements of market correcting and market making. This is why previous studies have primarily analyzed policies or EU laws that are straightforward in their categorization (Scharpf 1996, 1997a; Zürn 1997, 2002). Yet even on the level of individual legal acts, things may become at times difficult. Surrendering to the methodological challenge might be tempting but would make the theoretical distinctions of policies made by Lowi or Scharpf empirically irrelevant. I try to tackle the challenge by analyzing the general goals the EU aims to achieve within a certain policy sector, its underlying problem-solving approach, and the policy instruments mainly invoked to achieve these goals. This allows me to determine the predominant character of a policy sector. My categorization is certainly not beyond criticism but provides a first cut into an important research area (cf. Börzel, Hofmann, and Sprungk 2003; Börzel, Hofmann, and Panke 2011).

Agriculture was meant to be part of building a common market. While the member states subsequently removed tariffs on agricultural products, they set up a system of agricultural subsidies, which has prevented free competition. Being predominantly redistributive, the EU has heavily regulated production to bring rising production down and stabilize prices - the milk quota regime was only abolished in 2015. The increasingly contested regulatory dimension of the common agricultural policy, which also shows in the most infringed legal acts being regulatory, is market correcting in the sense that it aims at protecting the farming sector against the free market. 
Enterprise \& Industry had no clear legal base until the Treaty of Maastricht introduced the rather broad goal to ensure conditions necessary for the competitiveness of the industry (Article 173 TFEU). A closer look at the directives adopted in this policy sector shows that the main goal appears to be the approximation of laws regarding product standards. One could argue that Enterprise \& Industry is reregulating the market created by Internal Market-making policies. Its policies, however, seek to eliminate nontariff barriers, such as different technical standards, rather than correcting market failures. The most infringed legal act in this sector is a directive laying down a procedure for the provision of information in the field of technical standards and regulations. Article 28 TFEU prohibits quantitative restrictions on the movement of goods and measures having an equivalent effect, such as technical standards and regulations. Member states may still issue them where they are necessary in order to meet essential requirements and are in the public interest. The directive obliges the member states to notify the Commission about their intent to adopt a technical provision to give the Commission time to voice its objection, make amendments, or to consider the adoption of an EU directive. ${ }^{20}$

Information Society \& Media seeks to establish a Digital Single Market (Articles 179-180 TFEU). A range of regulations is intended to remove barriers to competition. Similar to Transport \& Energy, however, (tele)communications used to be a public service, so as to guarantee universal access even in remote or otherwise unprofitable areas. With the creation of the Internal Market, state monopolies were subsequently privatized, requiring some reregulation of the provision of services at the EU level to ensure that customers and businesses have fair and affordable access to networks and services, and that their data is protected. Accordingly, the two sectors have become predominantly market correcting, protecting consumer rights. Network neutrality is a prominent example. It is part of the universal service framework. Providers of internet access must not discriminate between services offered online, or give one preferential treatment over the other. Several network providers have started to offer their users subscription plans that would allow them to continue using certain services, such as WhatsApp and Spotify, even if their monthly data allowance expired. Competing chat apps and streaming services are blocked. While this is about fair competition, network neutrality is an individual and enforceable right of EU citizens as end users. ${ }^{21}$

\section{CONTROL VARIABLES}

The age of a sector is easy to determine. It is measured in the number of years the EU has had the competence to legislate. Not surprisingly, the EU had obtained competencies in most market-making sectors, as well as in Agriculture, already with the Treaty of Rome (1958), while market-correcting competencies only came later with 
the Single European Act (1986). The youngest sectors are JAIN and Employment \& Social Affairs, which were only created by the Maastricht Treaty (1992).22

Rather than the length of time the EU has held the competence to legislate on a sector, EU competence captures the level and scope of the EU's legal authority. The formal allocation of EU competencies and the institutional decision-making procedures as they evolved in the various treaty reforms provide an adequate operationalization (cf. Scharpf 2001b). The integration index developed by Börzel (Börzel 2005; cf. Schimmelfennig and Winzen 2014; Nanou, Zapryanova, and Toth 2017) captures the level (breadth) of integration by the number of issues in a given policy sector for which the EU has the power to legislate. The scope (depth) is measured in terms of the procedures according to which policy decisions are taken, focusing on the involvement of Commission (agenda setting) and European Parliament (consultation, cooperation, co-decision) and Council voting rules (unanimity, majority voting). For each of the two dimensions, a five-point scale is applied. In order to come to a more differentiated assessment, the scale also allows for half points. Since there is no theoretical reason to weigh level and scope differently, the average of the two scores is used. Agriculture and Internal Market are the sectors where the EU received a broad range of competencies subject to supranational decision making early on. In Enterprise, Environment, Consumer \& Health, and Employment \& Social Affairs the EU broadened its regulatory powers with every treaty reform, and directives became increasingly passed under what now is the ordinary procedure. The Commission has the exclusive right to introduce EU legislation, on which the Council votes by majority; the Parliament's approval is necessary to pass the bill, which is subject to the judicial review of the ECJ. Taxation, ${ }^{23}$ Transport \& Energy, and Information Society \& Media are at the other end of the integration spectrum, where the EU's formal powers have remained more limited and it is more difficult to form a consensus in the Council because of often-still-required unanimity (the unanimity requirement does not apply to Information Society \& Media).

EU support for the EU is usually measured at the country level in terms of public support for membership in the EU (see chapter 3). To tap into EU opposition against the EU's legal authority in a sector, I use Eurobarometer time series data on public support for transferring legislative competences in a specific policy sector to the European level.

As for the regulatory density of policy sectors, I look at the latitude of the EU's regulatory activities. This can be measured in two ways: first, by the rate of directives adopted in one sector in relation to all eleven sectors, and second, by the number of adopted directives in one sector in a given year. The second indicator is dynamic, varying by year. The two indicators highly correlate. I chose the second indicator for it is dynamic. 
For the four issue-specific control variables, misfit (new directives), complexity (recitals), delegated legislation (Commission directive), and EU-level conflict (EP amendments), I draw on the data sets developed for the analysis in chapter 4. For misfit and delegated legislation, I use the annual number of new directives and directives not delegated to the Commission, respectively, adopted in a sector three years prior to the official infringement. For complexity, I multiply the annual average of recitals based on directives in a sector by the number of directives adopted in the sector and divide the result by ten for reasons of rescaling. EU-level conflict is measured by the average stage at which the EP interferes in the adoption of a directive, pressuring the Council to make concessions by accepting amendments.

Finally, I use two dummy variables as controls for the effect of the Maastricht Treaty and the growing number of member states. More than any other treaty reform, the Maastricht Treaty substantially broadened and deepened the competencies of the EU, giving it the power to legislate on several new policy sectors, extending QMV in the Council, and empowering the European Parliament in the adoption of EU law. Between 1981 and 2012, the number of member states grew from ten to twenty-seven, increasing the violative opportunities.

The dependent variable is the absolute number of infringement proceedings per year and sector officially opened between 1981 and 2012 against violations of directives adopted three years before in the same sector. It is a count variable that is over-dispersed. The summary statistics can be found in table A1.5. Similar to what I did in chapter 4, I estimate a negative binomial regression with random effects to account for the pooled structure of the data. The Hausman test showed that unit-specific differences between years and sectors are coincidental. It is therefore not necessary to include fixed effects. Several of the issue-specific control variables check for violative opportunities.

Four control variables influencing compliance costs significantly correlate with each other since they are all linked to the number of adopted directives in a given year (see table A2.3). Regulatory density, misfit, delegated legislation, and complexity are therefore put into separate models. A fifth and six model control for the effect of the Maastricht Treaty and the growing number of member states, respectively.

\section{Results and Discussion}

POLICY TYPE AND REGULATORY LOGIC

The effect of regulatory policy is positive and significant in all models (table 5.1). The finding that regulatory policy is more prone to noncompliance finds further 


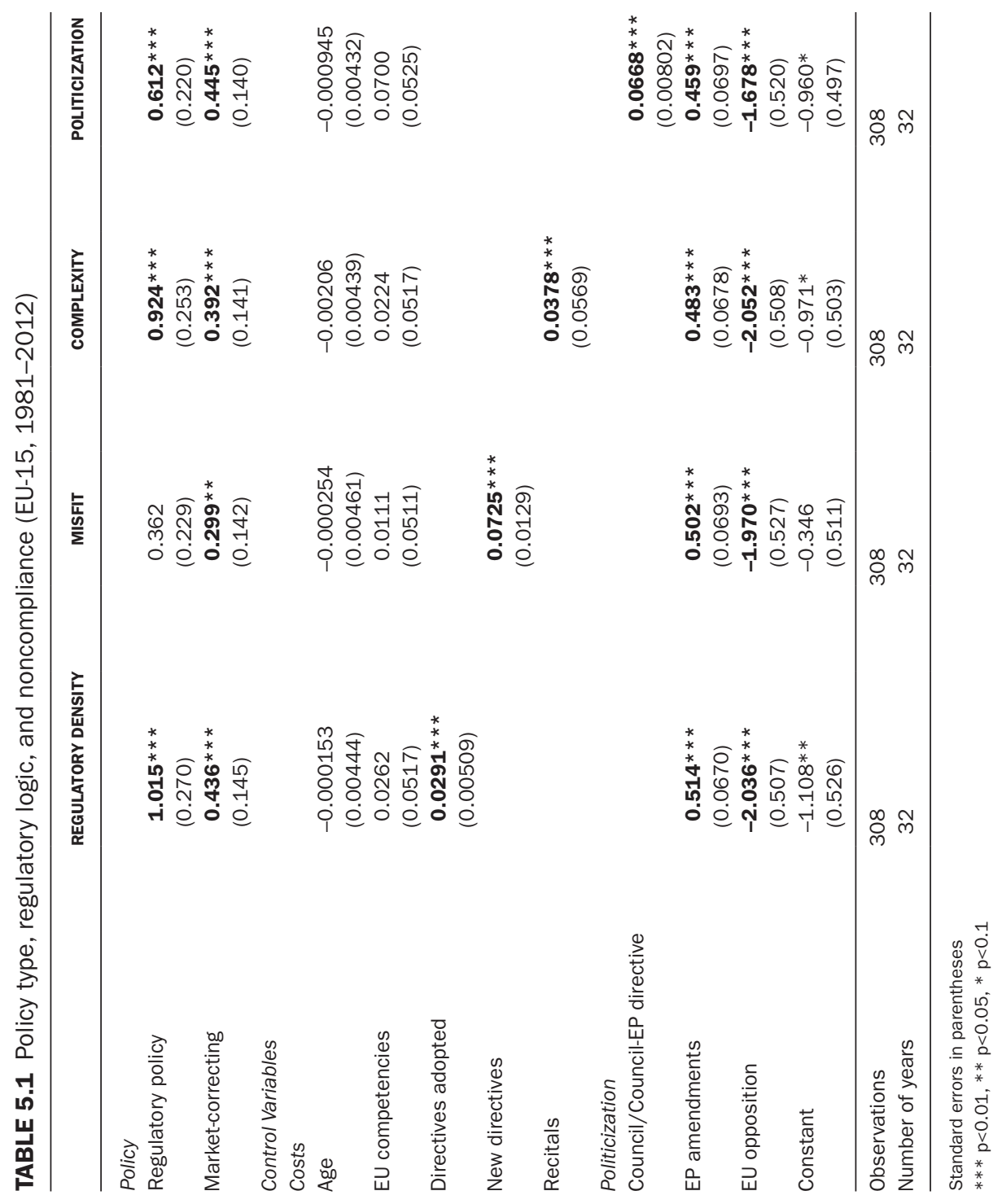


support by the omission of four nonregulatory sectors from the analysis. I did not include Fisheries \& Maritime Affairs, Regional Policy, Development, and Education \& Culture because violative opportunities are very low (less than one adopted directive in two years). These nonregulatory sectors hardly feature noncompliance (figure 5.1).

Likewise, market-correcting regulation has a positive and significant effect on noncompliance. Three of the four most infringed sectors, JAIN, Environment, and Health \& Consumer Protection, seek to harmonize national standards meant to protect individuals and their rights. Information Society \& Media has become increasingly concerned with data protection and universal access. By contrast, the lesser infringed sectors are predominantly market making or nonregulatory.

In sum, member states are more likely to violate regulatory policy, particularly if it aims at correcting market outcomes. Policy type and regulatory logic have a substantial effect on noncompliance.

\section{COMPLIANCE COSTS}

The results on the control variables confirm that sectors differ in the compliance costs they impose on the member states at the taking stage. The greater the level and scope of the competencies the EU has to set legislation and the higher the misfit (new directives) and the complexity (recitals) of the adopted legislation in a sector, the more noncompliance we are likely to see. Regulatory density (adopted directives) is significant, too, but appears to increase costs rather than alleviate them. This could be explained by regulatory density resulting in a higher workload, straining the capacity of the member states in taking EU directives (see chapter 4).

Age, in contrast, has a negative but not significant effect. This may have to do with EU competencies. On the one hand, extending the level and scope of EU competencies usually takes several treaty reforms. The older a sector, the more issues the EU is likely to be able to legislate on (level) and the more likely decision making is to be supranational (scope). On the other hand, market-correcting sectors tend to be younger. While market making has been at the core of European integration since its beginning, the Treaty of Rome of 1957 hardly conferred any market-correcting powers to the EU. This only started to change with the Single European Act. Environment is a case in point. The EU had selectively legislated on the sector more than ten years before the Single European Act of 1986 granted it the formal competence to do so. While the level of Article 130 (s) was already rather broad, member states had to decide by unanimity. Only the Maastricht Treaty of 1992 introduced qualified majority voting and gave the European Parliament a say in the adoption of EU environmental law. 


\section{POLITICIZATION}

Higher compliance costs result in more noncompliance. So does higher politicization. In the regression model, directives adopted by the Council and the EP increase the number of infringements (Council/Council-EP directive). Noncompliance becomes even more likely if conflict arises between the two co-legislators (EP amendments). With each additional stage of EP amendments, the expected infringements increase.

EU opposition, in contrast, makes noncompliance, if at all, less likely. It is the only variable that decreases the expected number of infringements. Its effect is significant in five of the six models. Similar to member state noncompliance, this counterintuitive correlation may be related to the effect of public opinion on EU decision making. Member state governments that face public opposition are empowered to shape EU law according to their preferences. They can also tie their hands when negotiating the transfer of new or the extension of existing competencies of the EU. These decisions require unanimity. Eurosceptic UK blocked the conferral of comprehensive competencies in Employment, Health \& Consumer Protection, JAIN, and Taxation. Opt-outs and other forms of differential integration have allowed the EU to eventually move forward with integrating these policy sectors (see chapter 4). Yet the scope and level of its competencies remain more limited compared to policy sectors where EU opposition is lower, such as Environment. The legal acts the EU has managed to pass tend to be frequently violated, particularly in market-correcting sectors. This explains why, despite the EU's more limited competencies, Health \& Consumer Protection and JAIN are among the most infringed policy sectors when controlling for violative opportunities. They have fewer legal acts than Environment; the member states, however, are equally likely to violate them because they are market-correcting regulatory policies and tend to get politicized, which may explain why the negative effect loses significance in politicized sectors.

The results on the variables influencing compliance costs and politicization support the findings of chapter 4 . Declining noncompliance is driven by the decreasing propensity of the EU to adopt new and complex directives, and the growing tendency of the member states to delegate the adoption of amending legislation to the Commission, which renders conflict between Council and EP impossible. These factors also seem to vary across sectors without leveling the effect of policy type and regulatory logic. Regulatory policy and market-correcting policy correlate negatively with the four variables related to compliance costs as well as with the adoption of directives by Council and EP, which all have a significant positive effect on noncompliance. Likewise, they show a positive correlation with EU opposition. EU conflict is the only factor conducive to noncompliance 
that correlates positively with the regulatory policy and market-correcting logic of a sector.

As in the country and the directive models, the explanatory power of PCP variables is rather robust in the sector model when including another five years (table A5.1).

\section{Policy Matters! The EU's Migration Crisis}

As expected by the PCP model, the policy type and the dominant regulatory logic of a sector have a significant effect on that sector's propensity for noncompliance. EU regulatory policy is more prone to violations, particularly if its regulatory logic is market correcting. The substantial costs incurred at the taking rather than the shaping stage of the compliance game are more likely to become politicized. While market-correcting policy creates winners and losers by opening markets, the domestic actors who have to bear the costs of EU market-correcting policy have to change their behavior to ensure compliance. This renders politicization of compliance costs more likely. The migration crisis, which hit the EU in 2015, is a powerful illustration of how politicization affects noncompliance with EU regulatory policy that incurs high costs at the domestic level.

In 2015, the EU found itself confronted with over 1.2 million refugees and migrants who had entered its territory. In order to cope with the historic influx, the majority of the member states agreed in September 2015 on an obligatory relocation quota. However, rather than many states sharing the burden, the vast majority of refugees and migrants ended up in a few member states. The failure of a common European solution is a clear demonstration of how difficult it is for member states to ensure compliance with EU regulatory policy that has redistributive costs at the domestic level when these costs become highly politicized. Even Germany and Sweden, which did not renege on their initial commitment to accept refugees, made available only a fraction of the places they had pledged. ${ }^{24}$ Three weeks before the relocation scheme expired on 26 September 2017, only 27,695 refugees (less than a quarter) out of the 120,000 legally foreseen in the Council decision of September 2015 had been relocated. ${ }^{25}$ Malta and Norway (a non-EU member state) are the only ones that fully met their relocation quota. With the exception of Finland, Ireland, Lithuania, Luxembourg, Malta, and Sweden, all other member states underperformed by more than 50 percent. The Commission officially opened infringement proceedings against Hungary, the Czech Republic, and Poland for neglecting their legal obligation to accept refugees from Greece and Italy. ${ }^{26}$ In 2015, it had already taken legal action against all twenty-eight member states for not applying the five directives the EU had 
adopted between 2001 and 2011 to provide minimum standards on asylum procedures and reception conditions for asylum seekers, temporary protection and recognition of refugees, and for the deportation of illegal migrants, as well as observing the Dublin and Eurodac fingerprinting regulations (European Commission 2016, 19-20). The increasing politicization of migration and asylum policy has made it more difficult to take the costs of complying with EU asylum and migration law. The regulatory measures substantially affect the allocation of refugees and migrants in the EU. Protecting their rights renders member states more attractive recipients, as the cases of Sweden and Germany demonstrate. Conversely, poor humanitarian conditions in reception centers and the setting up of detention camps where people are treated as criminals have a deterring effect.

As the PCP model would have expected, noncompliance with EU asylum and migration law had started well before the historic influx of more than a million refugees and migrants in 2015. Since the completion of the EU Common European Asylum System (CEAS) in 2005, the Commission had already sent more than three hundred reasoned opinions. Germany, Sweden, and Austria as primary destinations had hoped to make countries of first entry and transit countries more attractive for refugees and asylum seekers by shaping EU law as to harmonize standards for their reception, protection, and recognition. While those three countries had succeeded in uploading their policies to the EU level, Greece, Italy, Spain, Hungary, and Bulgaria have lacked the capacity to deal with rising numbers of persons in search of protection. ${ }^{27}$

Greece and Italy as member states of first entry stopped registering and accommodating migrants and refugees when their numbers started to increase in 2014. They have never really managed to return migrants not qualifying for asylum or refugee status to their country of origin (European Commission 2016, 9-10). Returning migrants to Greece as a country of first entry (Dublin transfers) has not been possible since 2010, not least because the European Court of Human Rights and the ECJ raised concerns about the human rights situation and the treatment of migrants in the reception centers (European Commission $2016,10) .{ }^{28}$ Rather than sharing the costs as required by EU law, Austria, France, Denmark, Sweden, and Germany reintroduced border controls. In the face of rising populism, member state governments felt unable to overcome the mounting public opposition to the reception and integration of refugees. While temporary border controls are admissible under the Schengen regime, the introduction of daily caps to restrict access of refugees in Austria and the building of razor-wire fences by Hungary and Bulgaria to stop them altogether are a blatant violation of both EU Schengen rules and international law.

The migration crisis is an exceptional example of noncompliance with marketcorrecting policy in the EU. As an extreme case, however, it illustrates clearly the 
underlying causal mechanisms specified by the PCP model. Market-correcting policy is more likely to become politicized because of its redistributive costs. Member state governments have used politicization fueled by populist parties to shape EU law in the EU's initial response to the migration crisis. At the same time, growing politicization had made compliance with the mandatory relocation scheme increasingly difficult, and not only in those countries that had been outvoted in the Council. Polarized public controversy over how to handle the refugee and migrant flows in the member states, as well as polarization in the European Parliament, has rendered any attempts at arriving at a common European solution through depoliticization by delegation futile.

In September 2015, Hungary, Slovakia, the Czech Republic, and Romania opposed the adoption of a temporary and exceptional mechanism to relocate 120,000 refugees from Italy and Greece to other member states over two years, on top of the 40,000 the member states had already decided to relocate. ${ }^{29}$ Germany, France, Austria, and Sweden had successfully tied their hands to the electoral success of right-wing populist parties that vigorously opposed the reception of further refugees and migrants. Since the Council passed the relocation decision under the non-legislative procedure, the EP was only consulted. In view of the urgent situation, the EP gave its consent to the Commission proposal without proposing any amendment, which would not have been binding for the Council anyway. The EP stressed, however, that it expected the Commission to prepare a proposal for a regulation of the European Parliament and of the Council to establish a crisis relocation mechanism..$^{30} \mathrm{~A}$ third of the parliamentarians either voted against or abstained, which indicates that relocation has been controversial in the EP, too. Particularly the Eurosceptic European Conservatives and Reformists Group has been opposed to any relocation scheme.

The EU-Turkey agreement on the resettlement of Syrian refugees required an amendment of the Council Decision of 2015. The resettlement agreement introduced a one-in, one-out policy. In exchange for each "irregular" migrant that Turkey took back from Greece, the EU would resettle one Syrian refugee from Turkey. Moreover, the EU allotted altogether $€ 6$ billion to help Turkey provide temporary protection for Syrians (European Commission 2016). The Council Decision of 2016 enabled member states to subtract from their allocated number of relocated applicants the number of Syrians admitted to their territory through resettlement from Turkey. The majority of EP members rejected that resettlement should take place at the expense of relocation. They also sought to extend the scope of the decision to Iraqis, Eritreans, and Afghans. Finally, the EP called on the member states to comply with their relocation commitments and agree on a holistic EU approach to migration. The EP introduced twenty-four amendments, which the Council chose to ignore. ${ }^{31}$ 
All attempts to institutionalize a permanent solution to deal with the continuing influx of migrants have failed so far. It has been impossible for the member state governments to ignore the increasing politicization of relocating even refugees. In line with the PCP model, the frontline states have continued to struggle with their lack of capacity to cope with compliance costs incurred by already agreed decisions and EU asylum and migration laws. In transit and destination countries, their taking has been undermined by mounting domestic opposition against receiving refugees. Even liberal Sweden has responded to the growing support for the right-wing populist Sweden Democrats by announcing a more restrictive approach. Germany has faced the rise in the polls of the antiimmigration party Alternative für Deutschland, resulting in the reneging on the Willkommenskultur (welcome culture) Chancellor Angela Merkel had advocated when Germany welcomed over 890,000 refugees in 2015 at the height of the crisis. As the most resourceful member state with a potent administration, it still has not been able to process the massive amount of pending applications for asylum, not to mention the proper housing and integration into the German labor market of the more than 1.2 million migrants Germany received in 2015 and 2016.

Facing mounting politicization at the EU level (EU-level conflict) and the domestic level (EU opposition), member state governments sought to delegate the regulation of migration to EU institutions. In 2016, the Commission proposed the computerized relocation of refugees enforced by an independent EU agency (cf. Börzel 2016). The European Asylum Support Office (EASO) would be turned into the European Union Agency for Asylum, with new powers to evaluate member states' policies. Moreover, the EU Border and Coast Guard Agency (EBCG) would monitor the EU's external borders to ensure that the member states effectively implemented EU legal standards for border management. In case of failure to do so, the EBCG would have the authority to intervene directly, without the consent of the member state concerned. A European Return Office, created within EBCG, would deploy European Return Intervention Teams to return illegally staying third-county nationals. The EU border guards would also enforce the mandatory and semiautomatic mechanism for redistributing asylum seekers and refugees, which the Commission suggested as part of the planned reform of the Dublin Regulation. ${ }^{32}$ The proposed distribution system would be activated whenever a member state faced a disproportionate number of asylum applications, namely more than 150 percent of its capacity. It would reflect the relative size, wealth, and absorption capacities of member states and would be monitored by the EASO. Member states refusing to accept asylum seekers would have to pay a $€ 250,000$ "solidarity contribution" to the hosting member state. A new regulation would amend the so-called Dublin III Regulation, 
circumventing the consent of national parliaments (European Parliament / European Council 2013).

The growing politicization of migration prevented the member states from delegating the handling of refugees and migrants to independent EU regulatory agencies. Instead, they have reverted to national solutions, comprehensively violating EU law. The reform of the EU's internal asylum system has deadlocked. The member states have not been able to agree on Commission proposals on how to grant and withdraw international protection, a list of safe third countries, reception conditions, labor market access for asylum seekers, residency permits for refugees and people with subsidiary protection status, guarding unaccompanied minors, and entering fingerprints of children into the Eurodac biometric database. The Salzburg Summit of September 2018 officially abandoned the idea of mandatory relocation. The new Commission president Ursula von der Leyen had promised a "fresh start on migration." ${ }^{33}$ Yet the Commission announced it would shelve its attempts at replacing the rule of first entry by a relocation mechanism because of the resistance of the Czech Republic, Hungary, and Poland. Its proposal for reforming the Common European Asylum System has focused on fortifying the EU's external border by increasing the budget and the personnel of the EBCG (cf. Börzel 2020).

Most Europeans consider immigration, together with terrorism, the most important issue for the EU and the member states. In 2017, some 68 percent of EU citizens supported a common migration policy; in only four of the twentyeight member states was a majority opposed. ${ }^{34}$ Yet member state governments are unwilling to confer on the EU the necessary competencies to effectively deal with the problem of protecting its external borders, of fighting human trafficking, and of preventing thousands of people from drowning in the Mediterranean. The times in which the EU could adopt regulatory policy without politics appear to be gone.

Policy determines the politics of noncompliance. Regulatory policy entails higher costs that are more likely to become politicized because of their redistributive consequences at the domestic level. This is particularly the case if the better part of regulatory policy aims at correcting market failure. Compliance research focuses on country variation and has not systematically explored nor explained sector-related noncompliance. The PCP model specifies how policy determines the politics of noncompliance by focusing on the differential effects of policy type and regulatory logic on compliance costs. First, because of the regulatory diversity of the member states with regard to the level of regulation but also their underlying regulatory philosophy, member states that have the power to shape EU market-correcting regulations according to their regulatory preferences are likely to face lower compliance costs. This is a function of public support for the 
EU. Eurosceptic member states are better shapers of the laws the EU adopts, as well as of its political authority to do so. Second, actively applying and enforcing EU regulations is more costly for the member states than simply abolishing national regulations or refraining from enacting new ones. Third, domestic resistance against compliance is more likely since domestic actors have to engage in costly change, and compliance costs tend to be unevenly distributed. The higher tendency of politicization may explain why the adoption of market-correcting policy is more likely to be delegated to the Commission, and why domestic opposition to EU competencies for market-correcting policy tends to be higher. If, however, market-correcting directives are adopted by the Council and the European Parliament instead of the Commission, conflict is likely to arise between the two co-legislators, increasing the propensity of the national parliaments to get involved in the transposition process, as shown in chapter 4 .

Monetary policy and immigration are two prominent examples of how member states have tried to address the redistributive implications of regulatory policy by depoliticizing them through delegation (cf. Börzel 2016). In both sectors, member states have not been willing to confer redistributive power to the EU. At the same time, EU regulations on the Monetary Union and the borderless Schengen area substantially constrain the member states in making redistributive policy at the domestic level. The convergence criteria and the Stability and Growth Pact deprive euro countries of key instruments of macroeconomic management without providing the EU with the tax and spending capacity to deal with external shocks and structural asymmetries within the Monetary Union. In a similar vein, the Schengen regime requires the participating countries to abolish internal border controls without creating a common external border control and a common administration to handle asylum seekers and refugees.

Unable to agree on a transfer mechanism to bail out member states in sovereign debt or at the front line of immigration, governments of creditor and nonrecipient member states have framed the euro and the Schengen crises as problems of too lenient rules and too lax enforcement. The solution, as they see it, is not fiscal transfer and relocation of refugees but compliance with stricter austerity, immigration, and border control rules, as well as structural reforms monitored and enforced by the Commission and independent EU agencies, such as the ECB, the ECBG, and the EOS. Compliance with EU rules is supposed to enable debtor and frontline countries to become self-sufficient in dealing with external shocks. Financial assistance is only a temporary means to buffer adjustment costs and help build reform capacities.

One could argue that EU monetary policy and immigration policy interfere with core state powers, which would explain why EU regulatory policy became so politicized, causing exceptional levels of noncompliance by which member 
states try to escape an equal distribution of costs. JAIN relates to internal security and is indeed the most infringed policy sector when controlling for violative opportunities. However, the degree to which EU environmental, health, and consumer regulations are contested in the member states and not complied with tells a different story. Member states have been very reluctant to grant the EU competencies to regulate issues that would directly interfere with their core powers (security, taxation, welfare). When not measured against the number of laws member states can potentially violate, JAIN ranks much lower on the sinners list (figure 5.1). The EU's noncompliance problems are concentrated in policy sectors the EU has comprehensively regulated because they are at the core of its mission to realize the four freedoms constituting the Internal Market. Ignoring their redistributive implications or trying to mask them as regulatory problems that need to be depoliticized has merely fueled the politicization of the EU (Börzel and Risse 2018). Isolating controversial policy from democratic politics by delegating its adoption to independent EU agencies has emboldened the calls of right- and left-wing populists to restore the sovereignty of the member states as the most effective way to protect citizens against financial markets, migration, civil rights activism, or terrorism. Market correction has ultimately turned into policy with politics. 